\title{
Isolation of bovine foamy virus in Japan
}

\author{
Yuma HACHIYA ${ }^{1)}$, Kumiko KIMURA ${ }^{2)}$, Keisuke OGUMA ${ }^{1)}$, Mamiko ONO ${ }^{1)}$, \\ Tetsuya HORIKITA ${ }^{1)}$ and Hiroshi SENTSUI ${ }^{1) *}$
}

\footnotetext{
${ }^{1)}$ Department of Veterinary Medicine, Nihon University, Kameino 1866, Fujisawa, Kanagawa 252-0880, Japan

${ }^{2)}$ National Institute of Animal Health, National Agriculture and Food Research Organization (NARO) 3-1-5 Kannondai, Tsukuba, Ibaraki 305-0856, Japan
}

\section{J. Vet. Med. Sci. \\ 80(10): 1604-1609, 2018}

doi: 10.1292/jvms.18-0121

Received: 6 March 2018

Accepted: 20 August 2018

Published online in J-STAGE:

3 September 2018

\begin{abstract}
Bovine foamy virus (BFV) is endemic in many countries, but has not been reported in Japan. A syncytium-forming virus was isolated from peripheral blood leukocytes of clinically healthy cattle on a farm in Kanagawa prefecture during a periodic epidemiological survey of viral diseases. The isolate was propagated in primary fetal bovine muscle cells and subsequently passaged in Madin-Darby bovine kidney cells. Since the isolate appeared to be distinct from the viruses with syncytium-forming ability previously isolated in Japan, we attempted to identify it using genomic analyses and electron microscopy. A phylogenetic analysis revealed that the isolate belongs to the bovine foamy virus cluster and is highly similar to a BFV strain isolated in China. A sero-epidemiological survey was performed using agar gel immunodiffusion test with the isolated virus as the antigen, and five of the 57 cattle tested were found to be seropositive.

KEY WORDS: bovine foamy virus, cattle, retrovirus, spumavirus, syncytium
\end{abstract}

Foamy viruses are members of the subfamily Spumaretrovirinae within the family Retroviridae characterized by unique features of their replication strategy and molecular biology [18]. They are commonly found in primates, cats, horses, and cattle [6, 10, 24, 28, 30]. Bovine foamy virus (BFV) was first isolated from clinically normal cattle in 1969 and is present in a high percentage of livestock cattle in various parts of the world $[1-3,13-15,21,32]$. It was initially presumed that BFV might be related to bovine lymphosarcoma, but the results of additional studies have not supported this hypothesis and the pathogenicity of BFV is unclear [4, 22]. Although foamy viruses are considered nonpathogenic, infection by these viruses may be associated with transient health abnormalities resulting from persistent infection and integration of viral DNA into the host genome [7, 19]. To date, BFV has not been isolated in Japan. Recently, we conducted an epidemiological survey on a farm in Kanagawa prefecture in Japan to identify cattle persistently infected with bovine viral diarrhea virus. A syncytium-forming virus was successfully isolated from peripheral blood leukocytes (PBLs) of clinically healthy cattle. Because the isolate appeared to be distinct from other syncytium-forming viruses previously isolated in Japan (e.g., bovine respiratory syncytial virus, bovine parainfluenza virus 3 , bovine herpesvirus 1 , bovine leukemia virus and bovine immunodeficiency virus), we attempted to identify the isolate and confirmed the first isolation of BFV in Japan.

\section{MATERIALS AND METHODS}

\section{Blood samples and virus isolation}

Fifty-seven cattle, 6 sheep, and 12 goats reared on a farm in the Kanto district of Japan were used in this study. Blood was collected from the tail vein of the cattle and from the jugular vein of the sheep and goats. Plain tubes were used for serum collection and EDTA-containing tubes were used to obtain PBLs. After lysis of erythrocytes by mixing with two volumes of $0.83 \%$ $\mathrm{NH}_{4} \mathrm{Cl}$ solution containing $0.01 \%$ EDTA, PBLs were separated from blood and washed three times in PBS with centrifugation at $1,000 \mathrm{rpm}$ for $10 \mathrm{~min}$. PBL concentration was adjusted to $1 \times 10^{7} / \mathrm{m} l$ and used for polymerase chain reaction (PCR) and virus isolation. One $\mathrm{m} l$ of PBL suspension $\left(1 \times 10^{7}\right.$ cells $)$ was co-cultured with $1 \mathrm{~m} l$ of fetal bovine muscle $(\mathrm{FBM})$ cells $\left(1.5 \times 10^{5}\right.$ cells $)$ in 6-well plates for virus isolation. After $48 \mathrm{hr}$, the infected cells were washed with Eagle's minimal essential medium (Eagle's MEM) (Nissui Pharmaceutical Co., Ltd., Tokyo, Japan) and fresh medium was added. The cells were cultured for a minimum of seven days. If a cytopathic effect (CPE) was not observed, blind passage was carried out using two methods: (i) subculture of infected cells by trypsinization, and (ii) inoculating uninfected cells with the culture medium. The passaging was performed twice.

\section{Cell culture}

FBM cell cultures were prepared by standard tissue-culture methods [25], and used within 20 passages for virus isolation and 
viral antigen preparation. Madin-Darby bovine kidney (MDBK) cells were employed for viral antigen preparation of the isolated virus for agarose gel immunodiffusion (AGID) tests. FBM cells were cultured at $37^{\circ} \mathrm{C}$ in Eagle's MEM containing $10 \%$ fetal calf serum (FCS), and MDBK cells were cultured under similar conditions in Eagle's MEM containing 5\% FCS and 0.3\% tryptose phosphate broth. To observe syncytium formation, the cells were fixed with methanol when CPE was observed and stained with Giemsa. Uninfected FBM cells were used as a negative control.

\section{Serological assays}

A total of 57 serum samples collected from farm-reared cattle were initially used to conduct the seroprevalence survey against the BFV isolate, and subsequently, sera from sheep and goats were included as well.

BFV-infected MDBK cells were used as antigens for the AGID tests. Infected cells were detached from the culture bottle using a rubber policeman when CPE had appeared in about $75 \%$ of cells, collected in a centrifugation bottle, and washed three times in PBS with centrifugation at 2,500 rpm for $10 \mathrm{~min}$. Cells were resuspended in a small volume of PBS containing $0.1 \%$ triton X-100 (approximately $1 / 100$ volume of original cell suspension culture fluid), sonicated, and used as the antigen for AGID tests.

AGID tests were performed according to the methods described by Malmquist et al. [22] and Kono et al. for bovine leukemia virus [17] with minor modifications. The wells were $5 \mathrm{~mm}$ in diameter, and six circumferential wells were placed at a distance of $3 \mathrm{~mm}$ from the central well. The central well was filled with the antigen and two side wells were filled with positive control serum. The other four wells were filled with undiluted test serum samples. The gel diffusion plate was incubated at room temperature for 2 days and precipitation lines were observed. Samples were regarded as positive when a precipitation line was formed and continuously joined with the positive control line formed between the antigen well and the positive control serum well. If a precipitation line was not formed but the control line curved marginally toward the inside of the test serum well, the sample was regarded as weakly positive. A positive control antiserum for the AGID assay was identified among serum samples collected from cattle on the farm. It yielded a single dense precipitation line that was specific for the BFV isolate, as demonstrated by an identical AGID reaction observed using a post serum from a rabbit 30 days after experimental infection with the virus.

\section{Positive control sera}

Because rabbits are sensitive to a simian foamy virus [12], we first attempted to prepare positive control sera by infecting a rabbit. RK13 cells, originating from rabbit kidney, were inoculated with the isolated virus and using this for immunization. A rabbit was intramuscularly inoculated with $1 \times 10^{7}$ virus-infected RK13 cells three times at 10 -day intervals. Serum taken 10 days after the final immunization formed a precipitation line in the AGID test, but the line was not clear enough to be used as a positive control. Therefore, a positive control antiserum for the AGID tests was selected among serum samples collected from cattle on the farm, tested to ensure specificity for BFV. The bovine serum formed a single dense precipitation line that connected with the line formed with the post serum of the immunized rabbit.

\section{Transmission electron microscopy}

For electron microscopy, infected FBM cells were detached from the petri dish using a rubber policeman. The cells were fixed with $2.5 \%$ glutaraldehyde in PBS, pelleted by centrifugation, post fixed with osmium tetroxide $(1 \%$ in $0.1 \mathrm{M}$ phosphate buffer, $\mathrm{pH}$ 7.4), dehydrated in graded ethanol, and embedded in LUVEAK-812 resin. Ultrathin sections were stained with uranyl acetate and lead citrate, and observed using a transmission electron microscope (H-7500, Hitachi High-Technologies Corp., Tokyo, Japan).

\section{DNA extraction from infected cells and PBLs}

Infected cells were trypsinized and washed twice in PBS. Approximately $2 \times 10^{5}$ cells that were resuspended in PBS were transferred to $1.5 \mathrm{ml}$ microcentrifuge tubes, and centrifuged at $2,000 \times \mathrm{g}$ for $5 \mathrm{~min}$. DNA was extracted from the cell pellet using DNeasy ${ }^{\circledR}$ Blood \& Tissue Kit (QIAGEN, Hilden, Germany) following the manufacturer's instructions. Subsequently, PBLs were collected from cow no. 43, which induced CPE on FBM cells by the procedure described in "Blood samples and virus isolation" above, and DNA was extracted directly from approximately $1 \times 10^{6}$ cells and subjected to PCR.

\section{Polymerase chain reaction}

To amplify a region of the BFV env gene using nested PCR, we modified the method described by Materniak et al. [23]. PCR was performed using the GoTaq Green Master Mix (Promega, Madison, WI, U.S.A.). The sequences of the first PCR primers were P1 (5'-tggactctagtagtctcacc-3') and P2 (5'-cttagaaagcgtggtaatggc-3'), and a 1,248-bp product was amplified. DNA was amplified using a thermal cycler (PCR Thermal Cycler Dice, Takara Bio Inc., Kusatsu, Japan,). The cycling conditions were as follows: one cycle of $95^{\circ} \mathrm{C}$ for $2 \mathrm{~min} ; 35$ cycles of denaturation $\left(95^{\circ} \mathrm{C}, 30 \mathrm{sec}\right)$, annealing $\left(55^{\circ} \mathrm{C}, 30 \mathrm{sec}\right)$ and extension $\left(72^{\circ} \mathrm{C}, 80 \mathrm{sec}\right)$; and one cycle of final extension $\left(72^{\circ} \mathrm{C}, 7 \mathrm{~min}\right)$. For the second PCR, $1 \mu \mathrm{l}$ of the first PCR product was reamplified using primers P3 (5'-tgtcattagaggacttcagg-3') and P4 (5'-ttgattgtcctgctatctgg-3'), and a 915-bp product was amplified. The PCR products were electrophoresed in $2 \%$ agarose gels and stained using ethidium bromide. The amplicons were purified using The Wizard ${ }^{\circledR}$ SV Gel and PCR Clean-Up System (Promega). BFV env gene sequences were analyzed using a BigDye Terminator v3.1 Cycle Sequencing Kit and an Applied Biosystems 3130 Genetic Analyzer (Thermo Fisher Scientific, Waltham, MA, U.S.A.).

\section{Phylogenetic analysis \\ Multiple alignment and phylogenetic analysis were performed using Clustal W in MEGA6 software [27]. A phylogenetic tree}




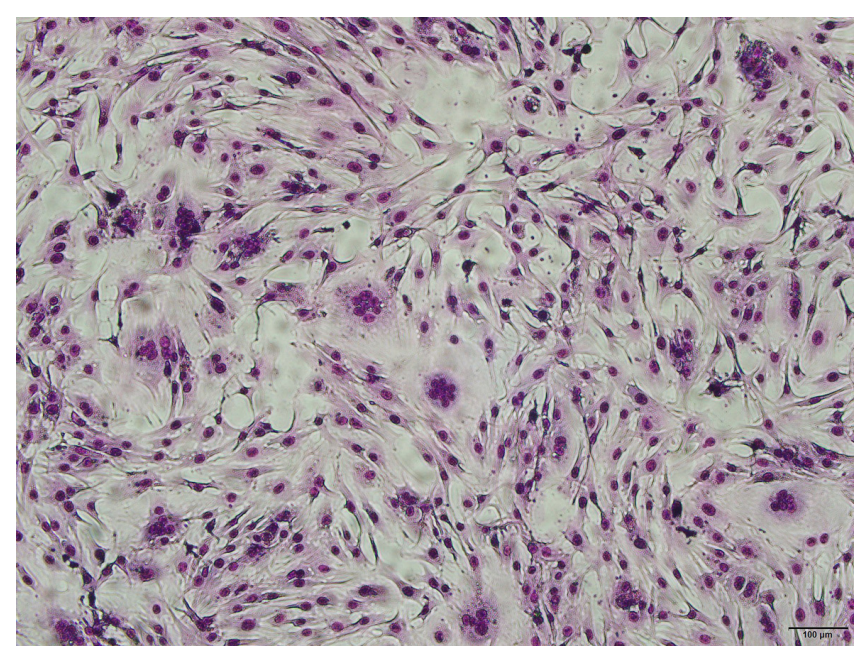

Fig. 1. Syncytium formed in FBM cells. FBM cells co-cultured with peripheral blood leukocytes from cow no. 43 were passaged twice and stained with Giemsa. Bar $=100 \mu \mathrm{m}$.

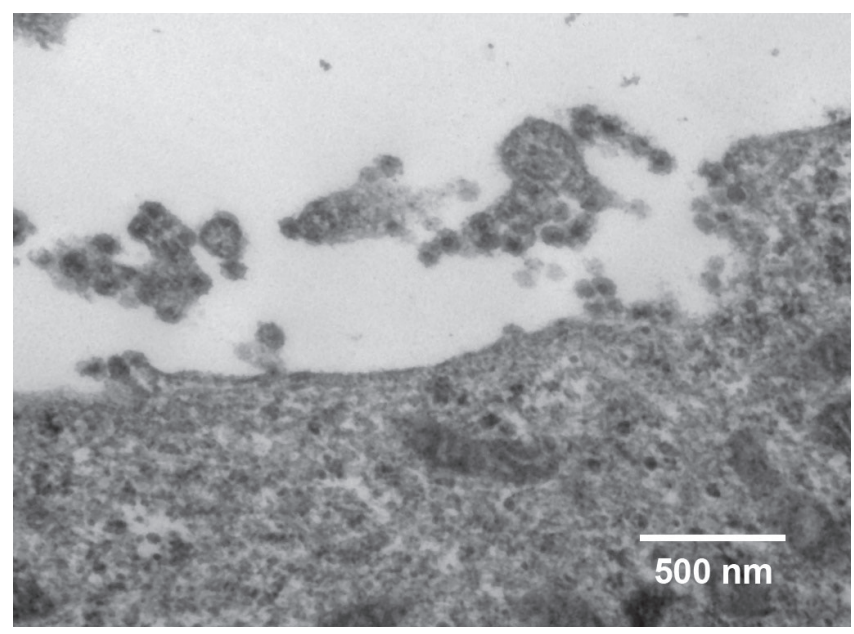

Fig. 2. Transmission electron micrograph of viral particles of isolate No. 43 grown in FBM cells. Bar=500 nm.

based on the partial env nucleotide sequences was generated by the Maximum Likelihood method based on the Tamura-Nei model [26], enabling comparison of nucleic acids in the same codon position. The analysis was done using eight sequences registered in GenBank, which include three isolated BFV strains; strain 3026 (AY134750), Riems (JX307862), strain 100 (JX307861), simian foamy virus (SFV, NC001364), equine foamy virus (EFV, NC002201) and feline foamy virus (FFV, NC001871).

\section{RESULTS}

\section{Virus isolation}

FBM cells co-cultured with cattle PBLs were passaged thrice. After the second passage, FBM cells co-cultured with PBLs from cow no. 43 demonstrated CPE. These cells were stained with Giemsa and syncytia were observed (Fig. 1). DNA extracted from these cells produced a positive result with BFV primers at the first PCR, but a negative result with primers for bovine leukemia virus, bovine immunodeficiency virus and sheep associated malignant catarrhal fever virus, even in nested PCR. FBM cells inoculated with other samples and materials showed no CPE after three passages. The isolate was temporarily named No. 43 and used in subsequent experiments. MDBK cells co-cultured with infected FBM cells also showed CPE and syncytia. BFV-infected FBM and MDBK cells were mixed at a ratio of 1:10 and cultured, and CPE was observed in more than $80 \%$ of the cells after 4-5 days. However, when FBM cells and MDBK cells were inoculated with cell-free supernatants from CPE-positive cells, neither developed CPE within 10 days of inoculation.

\section{Transmission electron microscopy}

Viral particles were identified in the infected FBM cells. The virions were spherical, enveloped and 80-100 nm in diameter (Fig. 2).

\section{Env gene sequence of the isolated virus}

FBM cells cultivated with PBL from cow no. 43 and which developed CPE yielded DNA that produced a band representing a 1,248 bp fragment in the first PCR and a 915 bp fragment in nested PCR. DNA extracted directly from PBLs from cow no. 43 formed a faint line in the first PCR and a clear positive line in nested PCR (Fig. 3). The partial env nucleotide sequences of both samples were identical and the isolated virus showed $98.9 \%$ homology when compared with the BFV reference strains (NC_001831) (Fig. 4).

\section{Phylogenetic analysis of viral env gene sequences}

A phylogenetic analysis using the isolate's env sequence was performed to confirm its identity as BFV. The isolate's env sequence was compared with those of viruses that have been previously reported as BFVs. Isolate No. 43 was most similar to the BFV strain 3026 (AY134750) and BFV-reference (NC001831), which were isolated in China and U.S.A. respectively [11, 33] (Fig. 5).

\section{Distribution of seropositive cattle on the farm}

Both BFV infected FBM cells and MDBK cells produced a clear precipitation line against the positive control serum in AGID tests when they were suspended in a small volume of PBS containing triton X-100 and sonicated. Because infected MDBK cells were easier to prepare, they were used as the antigen in AGID tests. Sera were collected from 57 cattle on the farm and tested for serum antibody against the isolate. Five cattle (8.8\%) were found to be seropositive. The seroprevalence survey was extended to 


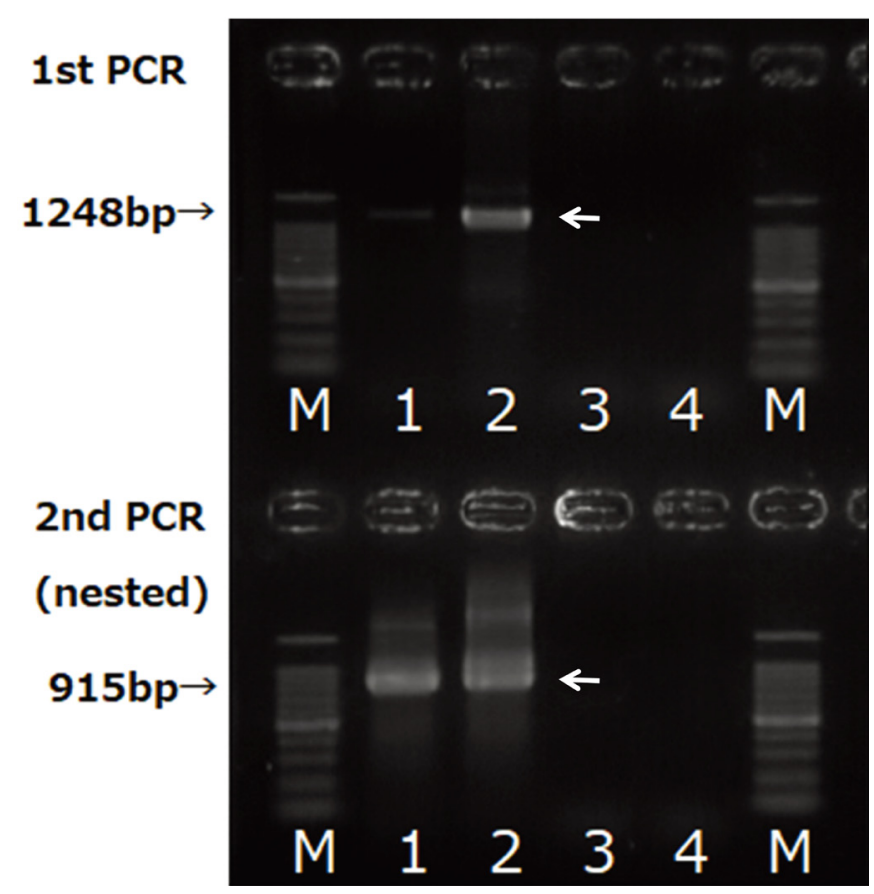

Fig. 3. PCR amplification of BFV env fragments. Genomic DNA was extracted directly from peripheral blood leukocytes (PBL) from cow no. 43 and FBM cells co-cultured with the PBL and passaged twice. Genomic DNA from the infected FBM cells (lane 2) yielded a 1,248-bp band in the first PCR. Both PBL (lane 1) and infected FBM cells yielded a 915-bp band, whereas DNA from uninfected FBM cells (lane 3) and autoclaved distilled water (lane 4) showed no amplification.

other ruminants on the farm, but no antibody-positive sera were detected among 12 goats and 6 sheep.

\section{DISCUSSION}

The virus isolated in this study, initially named isolate No. 43, was identified as a member of the genus Spumavirus in the family Retroviridae based on genomic analyses and electron microscopy. This is the first report of BFV isolation in Japan. BFV has been isolated in many countries, and seropositive cattle have been reported globally [3, 9, 13, 32], but not in Japan. One explanation may be that BFV has been of low interest to researchers because of its nonpathogenicity. BFV is highly cell-associated and only a small amount of cell-free virus is released from infected cells or tissues [14], thus making it difficult to isolate and culture. Since low infective titers of cell-free BFV are released into the culture medium in vitro, passage with virus-containing fluid is not effective [16]. Thus, there have been few opportunities for accidental BFV isolation during epidemiological surveys in the field.

The env sequence of isolate No. 43 was similar to previously described BFV env sequences in GenBank (Fig. 4). However, following detailed analysis, isolate No. 43 was found to be most similar to the BFV isolate from China and BFV-reference from U.S.A. [11, 32] (Fig. 5). BFV strains endemic to Asia may differ from those endemic to Europe, though the genomic differences between them are fewer. BFVs are globally distributed; however, it would be possible to classify the strains in each local region.

The route of natural infection by BFV is poorly understood. BFV persistently infects susceptible animals with an extended period of viremia, and infectious viruses may be excreted from infected animals. Therefore, BFV infection seems to occur by various routes and become prevalent among animals. However, only five of $57(8.8 \%)$ cattle in our study were found to be seropositive for BFV; this number is lower than the previously observed seroprevalence of bovine leukemia virus (BLV) in cattle $(31.6 \%)$, though both viruses have similar biological properties. BFV infection has been experimentally established by various routes [31], but infection is inconsistently established even if cell culture-derived virus is inoculated via intravenous and vaginal routes or via throat spray [14]. It is presumed that the spread of BFV infection is associated with intimate contact between cattle, and the source of infection is saliva from immunologically tolerant animals $[14,16]$. A positive clear reaction was barely observed in the nested PCR from DNA extracted from the PBL of cow no. 43 from which viruses had been isolated and which had BFV antibodies. It is probable that immunologically tolerant cows are not present on the farm, and the absence of such cattle appears to be the cause of the low percentage of infected cattle.

Cattle are considered to be the natural host of BFV. However, sheep can be experimentally infected with BFV, and a foamy virus has been isolated from sheep that appear to have been naturally infected [5, 23]. Therefore, we collected and examined sera from sheep and goats on the farm where BFV was isolated, and further sera from 60 sheep on other farms in the Kanto district were examined; however, they were all found to be antibody negative. Although the AGID test is less sensitive for antibody detection 

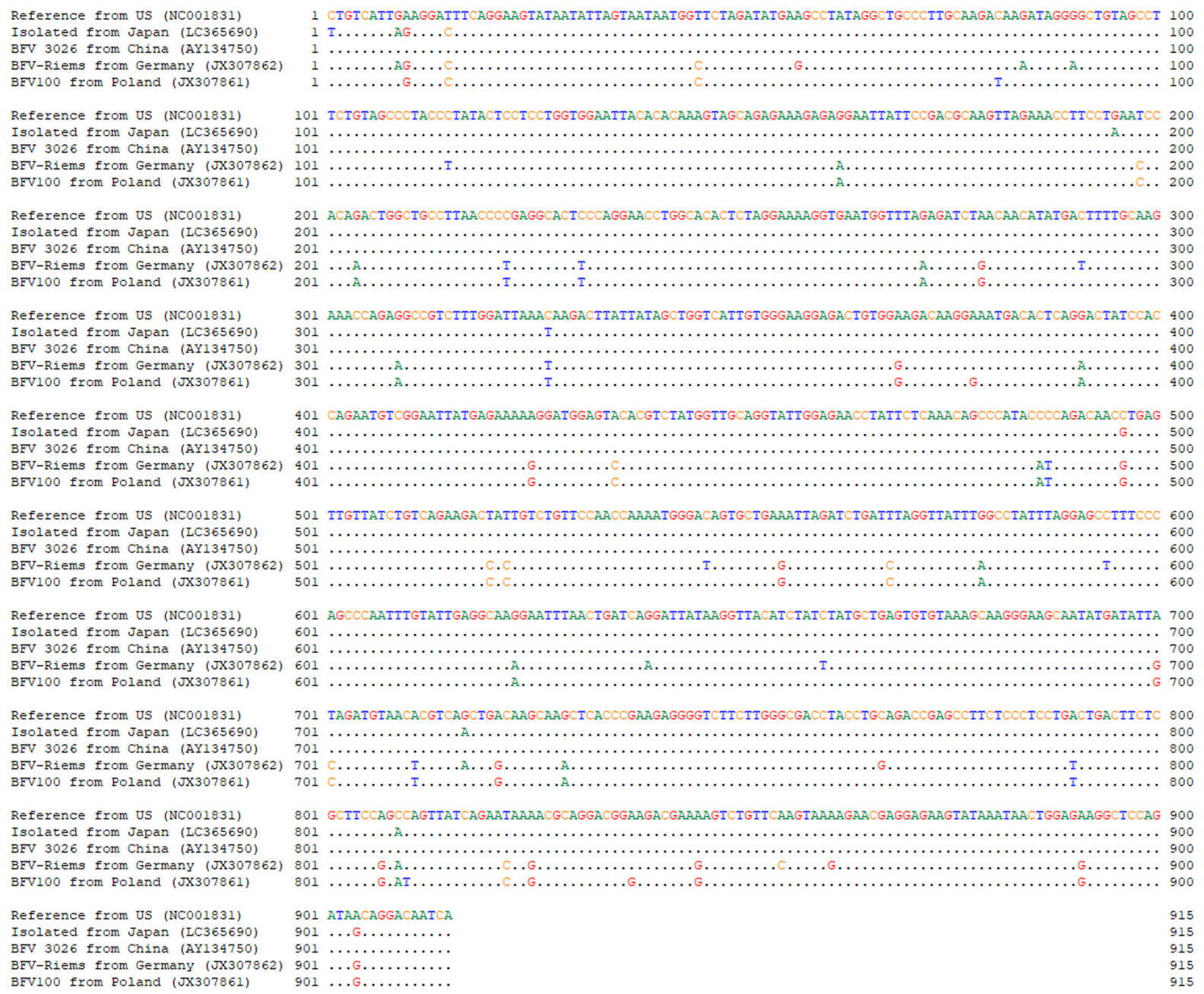

Fig. 4. Multiple sequence alignment of the partial env gene sequences from BFV isolate No. 43 (Isolated from Japan) and other BFV strains. Nucleotide identity is indicated by dots.

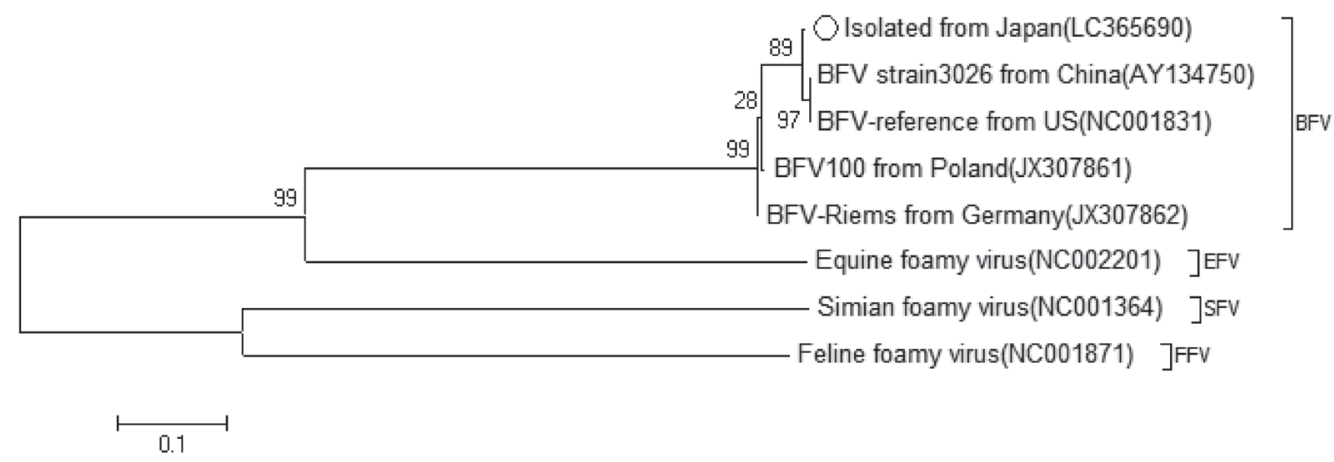

Fig. 5. Phylogenetic analysis of the BFV isolate (registration No. LC36590) and four other BFV strains and three outgroup strains (EFV, SFV, and FFV). The phylogenetic tree was generated using env of previously reported BFVs.

than ELISA or the virus neutralization test, it is possible to make a practical diagnosis if weak positive reactions are correctly detected based on experience. Therefore, natural infection of BFV in sheep was not prevalent.

Because the pathogenicity of BFV is unknown, it is difficult to indicate the treatment of infected cattle from the point of view of animal hygiene. However, as BFV is integrated in the genes of host cells and that infection persists, infected animals would be affected to some degree. Cattle-derived substances are used in various biological products. Fetal bovine sera are used for cell 
cultures that may then become contaminated with BFV $[8,30]$. Therefore, the numbers of BFV-infected cattle should be reduced, and the serological tests used in this study would be effective in detecting seropositive animals. Moreover, since the pathogenicity of BFV is very low, there is a possibility that it may be useful as a nonpathogenic vector in gene recombination techniques [20,29].

ACKNOWLEDGMENTS. This work was partly supported by the Academic Frontier Project for Private Universities S1491007 from the Ministry of Education, Culture, Sports, Science and Technology of Japan.

\section{REFERENCES}

1. Amborski, G. F., Lo, J. L. and Seger, C. L. 1989. Serological detection of multiple retroviral infections in cattle: bovine leukemia virus, bovine syncytial virus and bovine visna virus. Vet. Microbiol. 20: 247-253. [Medline] [CrossRef]

2. Appleby, R. C. 1979. Antibodies to bovine syncytial virus in dairy cattle. Vet. Rec. 105: 80-81. [Medline] [CrossRef]

3. Bansal, M. P. and Singh, K. P. 1980. Detection of antibodies of bovine syncytial virus among cattle and buffaloes in India. Indian J. Microbiol. 20: 198-200.

4. Boothe, A. D., Van der Maaten, M. J. and Malmquist, W. A. 1970. Morphological variation of a syncytial virus from lymphosarcomatous and apparently normal cattle. Arch. Gesamte Virusforsch. 31: 373-384. [Medline] [CrossRef]

5. Flanagan, M. 1992. Isolation of a spumavirus from a sheep. Aust. Vet. J. 69: 112-113. [Medline] [CrossRef]

6. Flower, R. L., Wilcox, G. E., Cook, R. D. and Ellis, T. M. 1985. Detection and prevalence of serotypes of feline syncytial spumaviruses. Arch. Virol. 83: 53-63. [Medline] [CrossRef]

7. German, A. C., Harbour, D. A., Helps, C. R. and Gruffydd-Jones, T. J. 2008. Is feline foamy virus really apathogenic? Vet. Immunol. Immunopathol. 123: 114-118. [Medline] [CrossRef]

8. Gould, E. A., Allan, G. M., Logan, E. F. and McFerran, J. B. 1978. Detection of antibody to bovine syncytial virus and respiratory syncytial virus in bovine fetal serum. J. Clin. Microbiol. 8: 233-237. [Medline]

9. Hechler, T., Materniak, M., Kehl, T., Kuzmak, J. and Löchelt, M. 2012. Complete genome sequences of two novel European clade bovine foamy viruses from Germany and Poland. J. Virol. 86: 10905-10906. [Medline] [CrossRef]

10. Herchenröder, O., Renne, R., Loncar, D., Cobb, E. K., Murthy, K. K., Schneider, J., Mergia, A. and Luciw, P. A. 1994. Isolation, cloning, and sequencing of simian foamy viruses from chimpanzees (SFVcpz): high homology to human foamy virus (HFV). Virology 201: 187-199. [Medline] [CrossRef]

11. Holzschu, D. L., Delaney, M. A., Renshaw, R. W. and Casey, J. W. 1998. The nucleotide sequence and spliced pol mRNA levels of the nonprimate spumavirus bovine foamy virus. J. Virol. 72: 2177-2182. [Medline]

12. Hooks, J. J. and Detrick-Hooks, B. 1979. Simian foamy virus-induced immunosuppression in rabbits. J. Gen. Virol. 44: 383-390. [Medline] [CrossRef]

13. Jacobs, R. M., Pollari, F. L., McNab, W. B. and Jefferson, B. 1995. A serological survey of bovine syncytial virus in Ontario: associations with bovine leukemia and immunodeficiency-like viruses, production records, and management practices. Can. J. Vet. Res. 59: 271-278. [Medline]

14. Johnson, R. H., de la Rosa, J., Abher, I., Kertayadnya, I. G., Entwistle, K. W., Fordyce, G. and Holroyd, R. G. 1988. Epidemiological studies of bovine spumavirus. Vet. Microbiol. 16: 25-33. [Medline] [CrossRef]

15. Johnson, R. H., Oginnusi, A. A. and Ladds, P. W. 1983. Isolations and serology of bovine spumavirus. Aust. Vet. J. 60: 147. [Medline] [CrossRef]

16. Kertayadnya, I. G., Johnson, R. H., Abher, I. and Burgess, G. W. 1988. Detection of immunological tolerance to bovine spumavirus (BSV) with evidence for salivary excretion and spread of BSV from the tolerant animal. Vet. Microbiol. 16: 35-39. [Medline] [CrossRef]

17. Kono, Y., Sentsui, H., Miyamoto, T., Morozumi, K. and Sakamoto, Y. 1982. Changes in antibody titers in cattle infected clinically and subclinically with bovine leukemia virus. Int. J. Cancer 30: 655-657. [Medline] [CrossRef]

18. Linial, M. L., Fan, H., Hahn, B., Löwer, R., Neil, J., Quackenbush, S., Rethwilm, A., Sonigo, P., Stoye, J. P. and Tristem, M. 2005. Retroviridae. pp. 421-440. In: Virus Taxonomy. (Fauquet, C. M., Mayo, M. A., Maniloff, J., Desselberger, U. and Ball, L. A., eds.) Elsevier Academic Press, London.

19. Linial, M. 2000. Why aren't foamy viruses pathogenic? Trends Microbiol. 8: 284-289. [Medline] [CrossRef]

20. Lindemann, D. and Rethwilm, A. 2011. Foamy virus biology and its application for vector development. Viruses 3: 561-585. [Medline] [CrossRef]

21. Lucas, M. H., Roberts, D. H., Parker, B. N. J. and Wibberley, G. 1986. Spread of bovine syncytial virus in a dairy herd over a two year period. Res. Vet. Sci. 40: 259-263. [Medline]

22. Malmquist, W. A., Van der Maaten, M. J. and Boothe, A. D. 1969. Isolation, immunodiffusion, immunofluorescence, and electron microscopy of a syncytial virus of lymphosarcomatous and apparently normal cattle. Cancer Res. 29: 188-200. [Medline]

23. Materniak, M., Hechler, T., Löchelt, M. and Kuzmak, J. 2013. Similar patterns of infection with bovine foamy virus in experimentally inoculated calves and sheep. J. Virol. 87: 3516-3525. [Medline] [CrossRef]

24. Saïb, A. 2003. Non-primate foamy viruses. Curr. Top. Microbiol. Immunol. 277: 197-211. [Medline]

25. Shimizu, M. and Satou, K. 1987. Frequency of persistent infection of cattle with bovine viral diarrhea-mucosal disease virus in epidemic areas. Nippon Juigaku Zasshi 49: 1045-1051. [Medline] [CrossRef]

26. Tamura, K. and Nei, M. 1993. Estimation of the number of nucleotide substitutions in the control region of mitochondrial DNA in humans and chimpanzees. Mol. Biol. Evol. 10: 512-526. [Medline]

27. Tamura, K., Stecher, G., Peterson, D., Filipski, A. and Kumar, S. 2013. MEGA6: Molecular Evolutionary Genetics Analysis version 6.0. Mol. Biol. Evol. 30: 2725-2729. [Medline] [CrossRef]

28. Tobaly-Tapiero, J., Bittoun, P., Neves, M., Guillemin, M. C., Lecellier, C. H., Puvion-Dutilleul, F., Gicquel, B., Zientara, S., Giron, M. L., de Thé, H. and Saïb, A. 2000. Isolation and characterization of an equine foamy virus. J. Virol. 74: 4064-4073. [Medline] [CrossRef]

29. Trobridge, G. D., Miller, D. G., Jacobs, M. A., Allen, J. M., Kiem, H. P., Kaul, R. and Russell, D. W. 2006. Foamy virus vector integration sites in normal human cells. Proc. Natl. Acad. Sci. U.S.A. 103: 1498-1503. [Medline] [CrossRef]

30. Van der Maaten, M. J., Hubbert, W. T., Boothe, A. D., Bryner, J. H. and Estes, P. C. 1973. Isolations of bovine syncytial virus from maternal and fetal blood. Am. J. Vet. Res. 34: 341-343. [Medline]

31. Van der Maaten, M. J., Malmquist, W. A. and Cheville, N. F. 1972. Susceptibility of calves to bovine syncytial virus given by different inoculation routes. Am. J. Vet. Res. 33: 1157-1160. [Medline]

32. Woode, G. N. 1972. Isolation of bovine syncytial virus in Britain. Vet. Rec. 91: 363. [Medline] [CrossRef]

33. Yu, H., Li, T., Qiao, W., Chen, Q. and Geng, Y. 2007. Guanine tetrad and palindromic sequence play critical roles in the RNA dimerization of bovine foamy virus. Arch. Virol. 152: 2159-2167. [Medline] [CrossRef] 